\title{
Amish nemaline myopathy
}

INSERM

\section{Source}

INSERM. (1999). Orphanet: an online rare disease and orphan drug data base. Amish nemaline myopathy. ORPHA:98902

Amish nemaline myopathy is a type of nemaline myopathy (NM; see this term) only observed in several families of the Amish community. 